\title{
PIK3AP1 Gene
}

National Cancer Institute

\section{Source}

National Cancer Institute. PIK3AP1 Gene. NCI Thesaurus. Code C147049.

This gene is involved in signaling from toll-like receptors and the B-cell receptor. 